\title{
Kajian titik kritis kehalalan produk olahan yoghurt
}

\author{
Dara Puspita Hapsaria, Endah Budi ${ }^{b}$, Setiyo Gunawan ${ }^{\mathrm{a}, \mathrm{c}, *}$ \\ aprogram Studi Teknologi Pangan, Departemen Teknik Kimia, Fakultas Teknologi Industri dan \\ Rekayasa Sistem, Institut Teknologi Sepuluh Nopember, Surabaya, 60111, Indonesia. \\ bBidang Keahlian Teknologi Pangan dan Gizi, Program Studi Gizi, Fakultas Kesehatan, \\ Universitas Nahdlatul Ulama Surabaya, Surabaya, 60237, Indonesia. \\ 'Pusat Kajian Halal, Direktorat Riset dan Pengabdian Masyarakat, Institut Teknologi Sepuluh \\ Nopember, Surabaya, 60111, Indonesia.
}

\begin{abstract}
ABSTRAK
Pasar global yang kini semakin meluas membuat konsumen harus lebih berhati-hati terutama ketika membeli produk makanan. Konsumsi makanan halal merupakan kewajiban bagi umat muslim. Salah satu produk makanan yang sedang banyak digemari beberapa tahun belakangan adalah yoghurt. Yoghurt diklaim memiliki banyak manfaat baik bagi kesehatan tubuh khususnya pencernaan karena mengandung bakteri baik atau probiotik. Yoghurt dibuat dengan melakukan fermentasi pada susu, dengan bantuan bakteri asam laktat. Sebagai produk hasil fermentasi yoghurt memiliki titik kritis kehalalan. Untuk menjaga tekstur yoghurt umumnya ditambahkan penstabil nabati maupun hewani. Pada artikel ini akan dibahas lebih dalam mengenai sejarah, proses pembuatan, komposisi serta titik kritis yoghurt berdasarkan studi literatur. Tujuan dari penulisan artikel ini adalah membantu pembaca untuk lebih memahami hal-hal yang perlu diperhatikan saat akan membeli produk olahan fermentasi yoghurt. Sebagai informasi tambahan terdapat 10 produk yoghurt yang banyak beredar di Indonesia yang akan dibandingkan komposisi serta status halal pada produk tersebut. Berdasarkan hasil perbandingan yang dilakukan, $80 \%$ produk yang banyak beredar di Indonesia sudah memiliki sertifikasi halal yang diakui MUI.
\end{abstract}

Kata kunci: Fermentasi, Halal, Telusur, Titik kritis kehalalan, Yoghurt.

C) 2022 Pusat Kajian Halal ITS. All rights reserved.

\section{Pendahuluan}

Indonesia merupakan negara kepulauan dengan jumlah penduduk yang cukup banyak. Berdasarkan data yang dirilis oleh Direktorat Jendral Kependudukan dan Pencatatan Sipil, Kementerian Dalam Negeri Indonesia, pada semester 1 tahun 2021, tercatat jumlah penduduk di Indonesia mencapai 272,23 juta jiwa [1]. Selain jumlah penduduknya yang banyak, Indonesia juga dikenal sebagai negara dengan mayoritas penduduknya yang memeluk agama Islam. Berdasarkan data yang disampaikan Kementerian Dalam Negeri,

\footnotetext{
* Corresponding author. Tel: +62 31 5946240; Fax: + 62315999282.

Email address: gunawan@chem-eng.its.ac.id
} 
$86,88 \%$ atau sekitar 236,5 juta penduduk Indonesia memeluk agama Islam. Pada 30 provinsi di Indonesia, jumlah penduduk yang beragama Islam lebih dari $50 \%$ atau Islam merupakan agama yang mayoritas. Sedangkan di 4 provinsi lainnya, Islam menjadi agama minoritas dengan pemeluk kurang dari 50\% [2]. Dengan jumlah tersebut, Indonesia menjadi negara dengan penduduk muslim terbanyak di dunia pada tahun 2021, diikuti Pakistan pada urutan kedua dengan 212,3 juta penduduknya beragama Islam, dan India di urutan ketiga dengan pemeluk Islam sebanyak 200 juta jiwa [3].

Sebagai negara dengan mayoritas penduduknya beragama Islam, syariat Islam sudah menjadi bagian dari kehidupan bermasyarakat, utamanya mengenai halal dan haram yang sudah menjadi pedoman hidup bagi umat muslim. Halal merujuk pada segala kegiatan yang baik bagi umat islam sehingga diperbolehkan. Allah SWT pertama kali mengajarkan mengenai perkara halal melalui wahyu yang disampaikan kepada Nabi Muhammad saw, dengan perantara malaikat Jibril, kemudian dibukukan menjadi Al-Quran yang kini menjadi pedoman hidup umat Islam. Makanan beserta turunannya disebutkan sebanyak 49 kali dalam Al-Quran dan terdapat instruksi yang sangat jelas tentang apa yang boleh dan tidak boleh dikonsumsi oleh umat islam, yaitu pada Q.S. Al-Maidah dan Q.S. Al-Baqarah [4]. Oleh karena syariat Islam memerintahkan umatnya untuk mengonsumsi makanan yang halal, maka kehalalan suatu produk makanan menjadi sangat penting. Dengan adanya pengaruh globalisasi, perpindahan penduduk dan barang dagangan dari suatu negara ke negara lain menjadi sangat cepat. Seiring dengan perkembangan tersebut, pasar halal global pun terus berkembang dan status kehalalan suatu produk (utamanya makanan) menjadi penting di era ini.

Proses sertifikasi halal di Indonesia yang saat ini dilakukan oleh Badan Penyelenggara Jaminan Produk Halal (BPJPH) yang bekerjasama dengan Majelis Ulama Indonesia (MUI) dan Lembaga Pemeriksa Halal (LPH) mengikuti prinsip telusur (traceability). Prinsip telusur berarti pelacakan dari mana suatu barang berasal dan ke mana barang tersebut dikirimkan. Prinsip yang diterapkan MUI ini menguntungkan bagi konsumen, dikarenakan jaminan halal tidak hanya dimiliki produk yang akan dikonsumsi, melainkan dari hulu atau tempat bahan baku dari produk tersebut [5]. Selain prinsip telusur yang diterapkan di Indonesia, ada beberapa mekanisme yang digunakan di negara lain, metode ini biasa disebut dengan analisa produk akhir (end-product analysis). Metode ini umumnya hanya memeriksa kandungan yang terdapat pada hasil akhir atau produk yang akan dipasarkan [6].

Yoghurt merupakan produk olahan dengan bahan dasar susu yang difermentasi dengan bantuan bakteri asam laktat yaitu Lactobacillus delbrueckii subsp. bulgaricus dan Streptococcus thermophilus [7]. Proses pembuatan yoghurt dimulai dari pemilihan bahan dan formulasi yang akurat untuk memproduksi yoghurt dengan kualitas yang baik. Semua produk susu yang digunakan sebagai bahan baku harus memiliki kualitas bakteorogikal yang baik untuk memberikan rasa yoghurt terbaik [8]. Yoghurt pertama kali ditemukan sekitar 10.00015.000 tahun yang lalu di Timur Tengah, karena adanya kontaminasi bakteri asam laktat pada susu yang disimpan dalam perut hewan. Kemudian yoghurt dikenal sebagai produk dengan kandungan probiotik yang baik untuk kesehatan. Selain itu, yoghurt juga memiliki kandungan vitamin dan beberapa keuntungan untuk kesehatan tubuh. Karena manfaatnya yang sangat banyak, kini yoghurt menjadi produk yang sangat populer dan banyak dicari oleh masyarakat 
[9]. Produk fermentasi susu diklasifikasikan menjadi tiga yaitu: (1) produk fermentasi laktat (mesophilic, thermophilic, dan probiotic), (2) produk fermentasi yeast-laktat, dan (3) produk fermentasi mold-laktat, dan yoghurt merupakan produk fermentasi laktat sama seperti keju [10].

Proses produksi yoghurt melalui fermentasi yang melibatkan adanya aktivitas mikroba memiliki titik kritis kehalalan yang mampu membuat produk yoghurt yang dihasilkan menjadi tidak halal. Titik kritis kehalalan produk mikrobial terletak pada tahap penyimpanan dan penyegaran mikroba. Selain itu asal mikroba tersebut juga merupakan titik kritis dari produk hasil fermentasi [11]. Selain itu pada proses pembuatan yoghurt terdapat tahapan penambahan zat aditif berupa perasa, pewarna dan penstabil, yang juga merupakan titik kritis kehalalan yoghurt [8]. Selain titik kritis kehalalan, produk olahan yoghurt ini juga memiliki titik kritis produksi yang ditetapkan oleh Badan Standarisasi Nasional (BSN), yaitu proses perlakuan panas, fermentasi, penambahan aditif hingga pengemasan [12]. Atma dkk. [13] menuliskan mengenai titik kritis kehalalan produk olahan bioteknologi, menurut artikel tersebut pada proses pengolahan yoghurt terdapat dua titik kritis kehalalan. Titik kritis kehalalan tersebur terdapat pada proses penyiapan starter dan juga penambahan zat aditif [13]. Namun, pada artikel tersebut tidak dijelaskan secara detail mengenai titik kritis kehalalan produk olahan yoghurt. Pada artikel ini akan dibahas lebih banyak mengenai proses produksi, dan titik kritis dari produk olahan yoghurt, serta beberapa merk yoghurt yang beredar di pasaran Indonesia saat ini. Adapun tujuan dari artikel ini adalah membantu pembaca memahami proses produksi dan titik kritis yang perlu diperhatikan saat akan mengkonsumsi yoghurt.

\section{Metode}

Metode yang digunakan dalam penulisan artikel ini adalah studi literatur atau pustaka. Studi pustaka adalah istilah lain dari kajian pustaka, tinjauan pustaka, kajian teoritis, landasan teori, telaah pustaka (literature review), dan tinjauan teoritis.

\section{Prinsip proses sertifikasi halal}

Sertifikat halal yang dimiliki suatu produk kini menjadi nilai tambah tersendiri, mengingat pasar halal global yang kian meluas. Pada umumnya terdapat dua metode penentuan kehalalan suatu produk, yaitu prinsip telusur (traceability) dan prinsip analisa produk akhir (end-product analysis). Menurut Mirghani dkk. [6] beberapa metode analisa yang umumnya digunakan adalah:

1. Gas Chromatography (GC), metode analisa ini umumnya digunakan untuk mengidentifikasi adanya kandungan bahan makanan yang tidak halal atau beracun dalam produk makanan yang dapat menyebabkan produk makanan tersebut menjadi tidak toyyib (baik) dan tidak halal.

2. Gas Chromatography - Mass Spectroscopy (GCMS), metode ini serupa dengan metode GC pada poin 1, namun menunjukkan hasil yang lebih akurat dan cepat dikarenakan menggunakan dua metode yang dikombinasikan.

3. High Pressure Liquid Chromatography (HPLC), metode ini banyak digunakan pada analisa makanan karena memiliki keunggulan dalam menganalisa bahan yang tidak tahan pada 
suhu tinggi. Beberapa penelitian menggunakan metode ini untuk menganalisa vitamin atau asam amino yang tidak tahan suhu tinggi.

4. Microscopic Determination (Microanalysis), umumnya menggunakan Scanning Electron Microscopy (SEM) dan Transmission Electron Microscopy (TEM). Metode ini memiliki keuntungan dikarenakan hasil yang didapatkan lebih detail dan dalam dibandingkan menggunakan mikroskop cahaya. Metode ini pernah digunakan untuk mengidentifikasi kulit yang berasal dari hewan tidak halal pada industri produk kulit (tas, sabuk, sepatu, dll.), metode inipun potensial untuk industri makanan.

5. Fourier Transform Infrared (FTIR) Spectroscopy, metode ini dapat menganalisa kandungan tidak halal seperti lemak babi pada lemak hewani, coklat, kue dan biskuit. Metode ini pernah digunakan untuk menganalisa beberapa bahan makanan seperti sari buah, selai, dan kopi.

6. Electronic Nose (E-Nose) Technology, metode ini menggunakan perubahan atmosfer yang diakibatkan senyawa kimia tertentu, pada industri makanan metode ini digunakan untuk mengetahui kandungan alhokol dalam suatu makanan.

7. Differential Scanning Calorimetry (DCS), metode ini memanfaatkan adanya perubahan secara fisika atau kimia pada suatu senyawa dengan adanya pengaruh perubahan suhu. Thermogram yang merupakan hasil dari analisa ini akan menampilkan kehadiran campuran dan senyawa tertentu misalnya minyak babi yang ditambahkan pada produk makanan.

8. Enzyme-linked Immunosorbent Assay (ELISA) technique, pada industri makanan umumnya digunakan untuk menganalisa kandungan babi dan turunannya pada makanan seperti sosis, daging kemasan, dll.

9. Molecular Biology Approach, umumnya menggunakan teknologi polymerase chain reaction (PCR) dengan cara menganalisa rantai DNA tertentu. Pada industri makanan metode ini dikembangkan dan banyak digunakan untuk mengidentifikasi keberadaan DNA babi dalam makanan.

10.Conventional Chemical Testing, umumnya digunakan pada analisa skala laboratorium, namun metode ini memiliki kekurangan karena banyaknya limbah yang dihasilkan.

Metode traceability yang diterapkan MUI memiliki beberapa keunggulan dibandingkan dengan metode end-product analysis di antaranya:

1. Mampu mengetahui status kehalalan suatu produk dari produsen bahan baku (hulu) hingga diterima konsumen (hilir), karena pada setiap tahapan proses produksi, penyimpanan, distribusi hingga pemasaran dijamin kehalalannya.

2. Status halal tidak hanya didapatkan oleh produk yang akan dipasarkan melainkan semua bagian yang berkontribusi dalam rantai pasok produk tersebut.

3. Untuk produk yang berasal dari rumah potong hewan, status kehalalan produk tidak hanya didapat ketika hewan merupakan hewan yang halal, namun juga ditentukan dengan teknik menyembelih yang digunakan.

4. Pada produk minuman, status kehalalan tidak hanya didapatkan pada minuman yang tidak mengandung alkohol melainkan juga melihat proses produksi minuman tersebut.

Disisi lain, metode end-product analysis juga memiliki keunggulan apabila dibandingkan dengan metode traceability, di antaranya: 
1. Memerlukan waktu yang lebih cepat untuk mengetahui kandungan tidak halal pada suatu produk.

2. Dapat menampilkan kandungan yang terdapat dalam suatu produk dengan lebih terperinci dan presisi.

Oleh karena prinsip telusur menawarkan jaminan halal rantai pasok, maka prinsip ini lebih aman untuk semua pihak yang terlibat utamanya konsumen. Saat ini Indonesia sedang menerapkan kebijakan yang mewajibkan setiap pelaku usaha baik skala besar atau UMK untuk memiliki sertifikasi halal agar dapat beredar di masyarakat. Kemenag menerapkan dua skema sertifikasi halal untuk UMK, yang pertama adalah mendanai sertifikasi halal untuk beberapa UMK dan yang kedua sesuai dengan amanat PP no. 39 Tahun 2021 di mana UMK yang sudah memenuhi standar yang ditetapkan BPJPH dapat melakukan self-declare terhadap kehalalan produk yang diperdagangkan [14].

\section{Sejarah yoghurt}

Yoghurt merupakan produk fermentasi susu yang sudah ditemukan sejak berabad-abad silam, fermentasi ini pada awalnya ditemukan secara tidak sengaja. Manusia yang pada saat itu sering melakukan perjalanan dan berpindah-pindah, menyimpan susu dalam perut sapi atau kambing, kemudian susu berubah menjadi asam dan sedikit kental. Kemudian fermentasi susu banyak dilakukan untuk mengawetkan susu supaya lebih tahan lama. Meskipun tidak ada catatan sejarah yang menyebutkan kapan pertama kali produk fermentasi susu dikembangkan, diperkirakan yoghurt berasal dari daerah Timur Tengah. Seiring berjalannya waktu, produk fermentasi susu ini berkembang di berbagai negara dengan nama yang berbeda-beda, dan kini lebih dikenal dengan sebutan yoghurt [7]. Susu yang merupakan bahan baku pembuatan yoghurt masih menjadi komoditi yang banyak diproduksi hingga saat ini. Pada tahun 2009, produksi susu global ditaksir mencapai 701,4 juta metrik ton. Dari data tersebut dapat dilihat bahwa produk susu dan olahannya tentu juga banyak beredar di pasaran. Tidak heran jika produk hasil fermentasi susu pun juga berkembang, dikarenakan keperluan untuk mempertahankan waktu simpan dari produk tersebut [15].

Yoghurt sendiri sudah dikenal sebagai produk olahan yang populer hingga saat ini. Dalam beberapa dekade terakhir, yoghurt mengalami kenaikan penjualan secara global. Hal ini tentu dikarenakan semakin banyak penemuan yang menyebutkan manfaat dari produk olahan susu ini. Bahan baku pembuatan yoghurt yaitu susu memiliki banyak kandungan nutrisi baik seperti protein, asam amino penting yang tersimpan dalam bentuk kasein dan whey protein, dan yoghurt sebagai produk olahan susu diklaim memiliki kandungan protein yang lebih tinggi dibandingkan susu. Hal tersebut menyebabkan yoghurt menjadi salah satu sumber protein yang baik [7]. Yoghurt yang diproduksi dengan menggunakan bakteri asam laktat, yaitu Lactobacillus dan Streptococus menyebabkan yoghurt mengandung jenis bakteri tersebut yang baik bagi kesehatan tubuh, terutama pencernaan. Selain itu yoghurt juga merupakan makanan yang baik dikonsumsi oleh anak-anak dikarenakan nutrisi di dalam yoghurt lebih mudah dicerna. Hal tersebut dikarenakan protein dalam susu sudah dicerna sebagian oleh 
enzim pada bakteri asam laktat dan kalsium pada susu terurai menjadi asam laktat yang lebih mudah diserap oleh tubuh [16].

Jauh sebelum yoghurt dan bakteri di dalamnya ditemukan dan dikembangkan, manusia sudah menyadari manfaat dari mengkonsumsi makanan asam seperti hasil fermentasi susu, buah dan sayur yang melalui proses fermentasi asam, dan cuka buah. Makanan tersebut diyakini memiliki kemampuan untuk menstabilkan asam di dalam tubuh dan membantu proses pembusukan serta penyerapan nutrisi dalam usus. Dari segi kesehatan, bakteri pembusukan dalam usus dijaga oleh bakteri asam laktat, yang juga membantu proses penyerapan nutrisi [16]. Seiring berkembangnya ilmu pengetahuan beberapa strain bakteri ditemukan memiliki manfaat bagi kesehatan, salah satunya adalah bakteri yang terkandung dalam yoghurt yaitu L. delbrueckii subsp. bulgaricus dan S. thermophilus yang mampu menghambat pertumbuhan beberapa strain bakteri seperti Salmonella, Shigella, Escherichia coli, dan Pseudomonas. IImu pengetahuan yang kian berkembang juga menyatakan bahwa susu menjadi media yang baik untuk kedua strain bakteri tersebut. Buffer pada protein susu membuat bakteri tetap aktif sampai ke saluran pencernaan [7].

\section{$5 \quad$ Proses pembuatan yoghurt}

Proses fermentasi yang dilakukan pada susu dengan tujuan mengawetkan susu sudah dilakukan sejak lama di Eropa, Asia, dan Afrika. Susu asam (susu yang mengalami fermentasi laktat) diklaim lebih stabil dibandingkan susu segar murni. Proses fermentasi membuat kandungan nutrisi yang terdapat dalam susu menjadi lebih stabil dan tahan lama [10]. Secara sederhana, proses pembuatan yoghurt beriringan dengan pertumbuhan bakteri baik (probiotik) di dalamnya seperti pada Gambar 1. Tekstur susu akan mengental apabila proses fermentasi asam laktat sudah terjadi. Hal tersebut dikarenakan terjadi pertumbuhan bakteri asam laktat yang berperan sebagai probiotik seiring dengan proses fermentasi berlangsung. Serta terjadi koagulasi protein yang terdapat dalam susu pada kondisi asam yang diakibatkan asam laktat yang diproduksi selama proses fermentasi [17]. Bakteri asam laktat yang digunakan pada proses fermentasi susu, terutama Lactobacillus delbrueckii subsp. bulgaricus dan Streptococcus thermophilus akan mengurai laktosa yang terdapat pada susu menjadi glukosa dan galaktosa dengan bantuan enzim $\beta$-galaktosidase, kemudian mencerna glukosa yang diubah menjadi asam laktat [18], [19]. Sampai saat ini belum ada teknologi yang dikembangkan untuk menggantikan proses fermentasi whole cell bakteri ini menjadi proses fermentasi enzimatik.

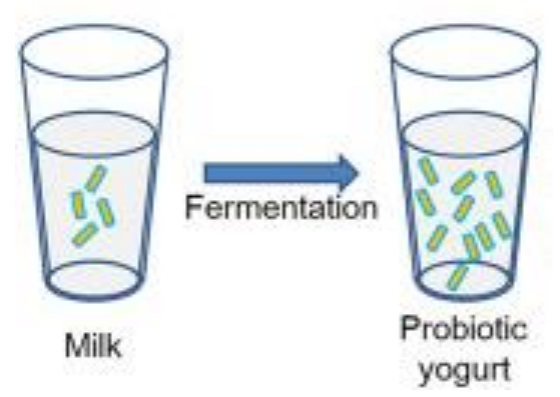

Gambar 1. Proses fermentasi susu menjadi yoghurt secara sederhana 
Adanya aktivitas mikroba pada proses pembuatan yoghurt tentu memicu adanya kontaminan berupa bakteri jenis lain yang mungkin terkandung di dalam bahan baku yaitu susu atau produk yoghurt. Kontaminan ini tentu dapat menghambat proses fermentasi dan merusak produk akhir serta dapat mengakibatkan yoghurt tidak layak dikonsumsi. Oleh karena itu, ada satu tahapan penting yang dilakukan sebelum proses fermentasi berlangsung, yaitu pasteurisasi atau pemanasan sampai suhu tertentu dalam waktu yang singkat. Proses tersebut memiliki tujuan untuk menghilangkan mikroba atau bakteri yang tidak diinginkan yang terdapat pada susu [20].

Sebagai salah satu produk hasil fermentasi maka proses pembuatan yoghurt sangat dipengaruhi oleh perbandingan antara karbon dan nitrogen. Pada perbandingan C: $\mathrm{N}$ yang rendah akan menurunkan kemampuan bakteri asam laktat yang digunakan untuk mengonversikan bahan baku menjadi produk yang diinginkan, dalam hal ini adalah yoghurt [21],[22]. Perbandingan $\mathrm{C}: \mathrm{N}$ juga mempengaruhi proses produksi emulsifier alami yaitu exopolysaccharides (EPS) yang diproduksi bakteri asam laktat [23]. Setiap bakteri memiliki kebutuhan perbandingan $\mathrm{C}: \mathrm{N}$ yang berbeda-beda, dan bakteri asam laktat memerlukan perbandingan $\mathrm{C}: \mathrm{N}$ sebesar 4.13 untuk menghasilkan asam laktat yang optimum [24]. Perbandingan antara karbon dan nitrogen biasanya dinyatakan dalam perbandingan antara massa karbon dan massa nitrogen. Perbandingan C:N sangat penting bagi mikroorganisme, dan setiap mikroorganisme memiliki kebutuhan $\mathrm{C}: \mathrm{N}$ yang bervariasi. $\mathrm{Di}$ mana semakin besar perbandingan antara $\mathrm{C}: \mathrm{N}$ dibandingkan perbandingan ideal yang dibutuhkan maka mikroorganisme akan mencerna suatu karbon dengan lebih lambat, karena kekurangan sumber nitrogen. Begitu pun apabila perbandingan antara $\mathrm{C}: \mathrm{N}$ yang semakin kecil, maka mikroorganisme hanya dapat menghasilkan produk dalam jumlah yang sedikit dikarenakan keterbatasan sumber karbon [25].

Pada awalnya yoghurt hanya dibuat dari susu yang disimpan di dalam lambung sapi atau kambing dan dibawa bepergian. Dalam lambung sapi dan kambing yang sudah dibersihkan ternyata mengandung bakteri asam laktat yang mampu mengawetkan susu dan membuat susu serta kandungan nutrisinya menjadi lebih stabil. Namun, rasa susu berubah menjadi lebih asam dan terdapat gumpalan berwarna krem di atas permukaan susu. Produk olahan tersebut kini dikenal dengan sebutan yoghurt [9]. Seiring berjalannya waktu dan berkembangnya ilmu pengetahuan kini dalam proses pembuatan yoghurt banyak melibatkan bahan tambahan lain di luar susu dan bakteri asam laktat. Seperti pada pembuatan mix yoghurt bahan bahan yang digunakan adalah susu murni, susu skim, susu skim kondensat dan lain sebagainya [8]. Blok diagram proses pembuatan yoghurt tertera pada Gambar 2.

Menurut Chandan (2017) [8], pada umumnya proses pembuatan yoghurt melalui langkahlangkah berikut:

1. Pencampuran, prosedur ini diperlukan untuk mencampur bahan-bahan padat dan cair agar menjadi larutan homogen.

2. Pasteurisasi dan pemberian panas, proses ini bertujuan untuk menonaktifkan bakteri patogen dalam susu, selain itu pada proses ini juga terjadi denaturasi whey protein sebesar 80-85\% yang meningkatkan konsistensi dan viskositas yoghurt. 
3. Homogenisasi, pada tahap ini partikel lemak yang terdapat dalam susu diperkecil sehingga membuat ukuran partikel menjadi lebih seragam.

4. Persiapan starter, tahap ini diperlukan untuk mempersiapkan starter bakteri sebelum akhirnya digunakan untuk proses produksi yoghurt.

5. Penambahan starter dan fermentasi, kemudian campuran yang sudah homogen tadi ditambahkan bakteri dan difermentasi pada suhu $42^{\circ} \mathrm{C}$ dan fermentasi dilakukan sampai $\mathrm{pH}$ mencapai 4,6.

6. Pendinginan, pendinginan ini dilakukan secara cepat yaitu selama 1 jam hingga mencapai suhu $18-20^{\circ} \mathrm{C}$, hal ini ditujukan untuk menghentikan proses pertumbuhan mikroorganisme.

7. Pengadukan, tahapan ini tidak boleh dilakukan terlalu cepat atau terlalu lama, karena dapat merusak konsistensi dari yoghurt, tahap ini penting terutama untuk produksi natural yoghurt.

8. Pemompaan, proses ini diperlukan untuk memindahkan yoghurt ke tempat penyimpanan, namun pompa yang dapat digunakan hanyalah positive drive pump saja.

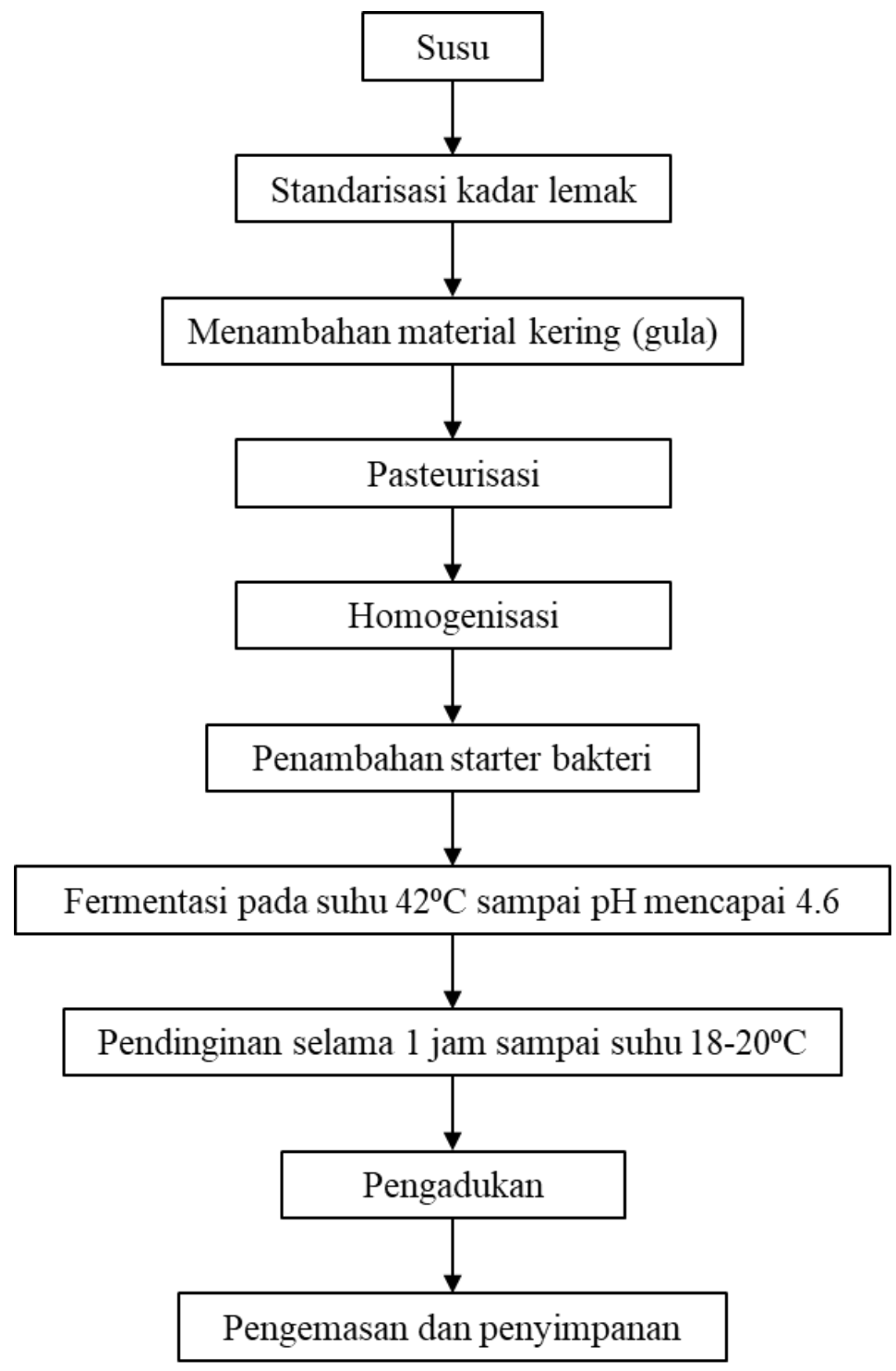

Gambar 2. Diagram alir proses produksi yoghurt 


\section{Standar mutu yoghurt}

Standar Nasional Indonesia (SNI) merupakan standar suatu produk yang dibuat oleh BSN yang digunakan untuk menilai apakah suatu produk tersebut layak edar atau tidak. Yoghurt merupakan salah satu produk yang sudah banyak beredar di Indonesia, sehingga BSN mengeluarkan SNI 2981:2009 mengenai standar yoghurt [26]. Adapun tujuan yang disampaikan BSN dalam pembuatan SNI yoghurt adalah untuk melindungi kesehatan konsumen, menjamin perdagangan pangan yang jujur dan bertanggung jawab, diverifikasi produk atau pengembangan produk, dan mendukung perkembangan industri yoghurt.

Pada SNI 2981:2009 tidak hanya membahas mengenai standar mutu yoghurt, tapi juga membahas mengenai definisi dan macam-macam yoghurt, serta bahan yang dibolehkan untuk digunakan dalam proses pembuatan yoghurt. Menurut SNI 2981:2009 yoghurt dikategorikan menjadi 3 jenis yaitu:

1. Yoghurt yang merupakan produk olahan hasil fermentasi susu dan atau susu rekonstitusi dengan bantuan bakteri L. bulgaricus dan S. thermophilus dan atau bakteri asam laktat lainnya yang sesuai, dengan atau tanpa penambahan bahan pangan lain yang diizinkan.

2. Yoghurt rendah lemak yang merupakan yoghurt yang dibuat dengan bahan baku susu rendah lemak atau susu rekonstitusi rendah lemak yang difermentasi.

3. Yoghurt tanpa lemak yang merupakan yoghurt yang dibuat dengan bahan baku susu skim atau susu skim rekonstitusi yang difermentasi.

Kemudian berdasarkan prosesnya dikelompokkan menjadi yoghurt tanpa perlakuan panas setelah fermentasi dan yoghurt dengan perlakuan panas setelah fermentasi. Standar mutu yoghurt menurut SNI sesuai dengan Tabel 1. Berdasarkan SNI 2981:2009 bahan baku utama pembuatan yoghurt adalah susu dan/atau susu rekonstitusi dengan atau tanpa lemak. Bahan tambahan pangan seperti perisa, pewarna, atau pemanis, adalah bahan bahan tambahan pangan yang sesuai dengan ketentuan yang beredar.

SNI sudah menjelaskan beberapa kondisi yang harus dipenuhi oleh produsen agar produk yoghurt yang dihasilkan sesuai dengan standar mutu yang telah ditetapkan. Standar mutu yang pertama adalah mengenai keadaan, secara normal yoghurt sudah memiliki penampakan yang kental (cair - padat) akibat adanya pertubuhan probiotik dan koagulasi protein susu pada kondisi asam serta memiliki bau dan rasa yang khas atau sedikit asam yang diakibatkan adanya asam laktat yang merupakan hasil dari fermentasi bakteri asam laktat. Untuk konsistensi, umumnya bahan baku yang mengandung banyak lemak akan menghasilkan yoghurt yang lebih homogen. Hal tersebut dikarenakan adanya kandungan eksopolisakarida (EPS) yang merupakan produk alami dari fermentasi. Namun apabila kandungan lemak pada susu sedikit atau bahkan tidak ada, struktur yoghurt yang dihasilkan akan menjadi kurang homogen, sehingga perlu ditambahkan pengemulsi [17],[24].

Cemaran logam yang terkandung dalam yoghurt berasal dari bahan baku dan proses pengolahannya. Beberapa analisa telah dilakukan untuk mengetahui kandungan cemaran logam pada susu dan yoghurt. Menurut Fadlina dkk. [28] pada susu kambing yang dianalisa tidak terdeteksi adanya cemaran logam timbal, namun terdapat cemaran logam arsen sebanyak 0,004291 mg/kg (ppm). Hasil tersebut masih berada di bawah batas yang ditetapkan SNI untuk standar mutu susu kambing SNI 01-3141-1998 yaitu 0,1 ppm [28]. 
Nasution [29] menyampaikan bahwa cemaran logam timah tidak terdeteksi pada hasil analisa susu pasteurisasi dikarenakan konsentrasinya yang sangat rendah. Namun, terdapat cemaran logam tembaga sebanyak 0,0093 - 0,1884 mg/kg (ppm). Hasil yang didapatkan untuk cemaran logam pada susu pasteurisasi masih berada di bawah ambang batas yang ditetapkan SNI 7387:2009. Silalahi dan Purwanti [30] melakukan analisa cemaran logam timbal pada produk olahan susu, di mana pada susu pasteurisasi terdapat cemaran logam timbal sebesar $0,001-0,020 \mathrm{mg} / \mathrm{kg}$ (ppm) dan pada yoghurt terdapat cemaran logam timbal sebesar 0,001 $-0,025 \mathrm{mg} / \mathrm{kg}$. Hasil analisa ini menunjukkan bahwa cemaran tersebut masih berada di bawah standar yang ditetapkan SNI mengenai batas maksimum cemaran logam berat dalam pangan, yang diatur pada SNI 7387:2009.

Sebagai produk yang melibatkan aktivitas mikroba, maka keberadaan cemaran mikroba sangat mungkin terjadi pada produk ini. Namun pada dasarnya keberadaan bakteri $L$. delbrueckii subsp. bulgaricus dan $S$. thermophilus atau bakteri asam laktat lainnya akan menghambat pertumbuhan beberapa bakteri seperti Salmonella, Shigella, E. coli dan Pseudomonas [7]. Namun seiring dengan lama waktu penyimpanan jumlah bakteri $L$. delbrueckii subsp. bulgaricus dan S. thermophilus akan terus berkurang, dan memungkinkan tumbuhnya bakteri yang tidak diinginkan. Menurut Diza dkk. [31] setelah penyimpanan selama 4 minggu, jumlah bakteri asam laktat dalam yoghurt mengalami penurunan dari 2,38 $\times 108 \mathrm{koloni} / \mathrm{g}$ pada $0 \mathrm{minggu}$ dan menjadi 6,0 × $105 \mathrm{koloni} / \mathrm{g}$ setelah disimpan selama 4 minggu dengan total asam yang cenderung meningkat. Berkurangnya jumlah bakteri asam laktat dalam yoghurt akan memberi kesempatan bakteri lain untuk tumbuh. 
Tabel 1. Syarat mutu yoghurt menurut SNI 2981:2009 [26]

\begin{tabular}{|c|c|c|c|c|c|c|c|c|}
\hline \multirow[b]{2}{*}{ No } & \multirow[b]{2}{*}{ Kriteria uji } & \multirow[b]{2}{*}{ Satuan } & \multicolumn{3}{|c|}{$\begin{array}{l}\text { Yoghurt tanpa perlakuan panas } \\
\text { setelah fermentasi }\end{array}$} & \multicolumn{3}{|c|}{$\begin{array}{l}\text { Yoghurt dengan perlakuan } \\
\text { panas setelah fermentasi }\end{array}$} \\
\hline & & & Yoghurt & $\begin{array}{l}\text { Yoghurt } \\
\text { rendah } \\
\text { lemak }\end{array}$ & $\begin{array}{l}\text { Yoghurt } \\
\text { tanpa } \\
\text { lemak }\end{array}$ & Yoghurt & $\begin{array}{l}\text { Yoghurt } \\
\text { rendah } \\
\text { lemak }\end{array}$ & $\begin{array}{l}\text { Yoghurt } \\
\text { tanpa } \\
\text { lemak }\end{array}$ \\
\hline 1 & \multicolumn{8}{|l|}{ Keadaan } \\
\hline 1.1 & Penampakan & - & \multicolumn{3}{|c|}{ cairan kental - padat } & \multicolumn{3}{|c|}{ cairan kental - padat } \\
\hline 1.2 & Bau & - & \multicolumn{3}{|c|}{ normal/khas } & \multicolumn{3}{|c|}{ normal/khas } \\
\hline 1.3 & Rasa & - & \multicolumn{3}{|c|}{ asam/khas } & \multicolumn{3}{|c|}{ asam/khas } \\
\hline 1.4 & Konsistensi & - & \multicolumn{3}{|c|}{ homogen } & \multicolumn{3}{|c|}{ homogen } \\
\hline 2 & Kadar lemak (b/b) & $\%$ & $\min .3,0$ & $0,6-2,9$ & maks 0,5 & $\min .3,0$ & $0,6-2,9$ & $\begin{array}{c}\text { maks } \\
0,5\end{array}$ \\
\hline 3 & $\begin{array}{l}\text { Total padatan } \\
\text { susu bukan lemak } \\
\text { (b/b) }\end{array}$ & $\%$ & & $\min .8,2$ & & & $\min .8,2$ & \\
\hline 4 & $\begin{array}{l}\text { Protein }(N \times 6,38) \\
(b / b)\end{array}$ & $\%$ & & $\min .2,7$ & & & $\min .2,7$ & \\
\hline 5 & Kadar abu (b/b) & $\%$ & & maks. 1,0 & & & maks. 1,0 & \\
\hline 6 & $\begin{array}{l}\text { Keasaman } \\
\text { (dihitung sebagai } \\
\text { asam laktat)(b/b) }\end{array}$ & $\%$ & & $0,5-2,0$ & & & $0,5-2,0$ & \\
\hline 7 & \multicolumn{8}{|l|}{ Cemaran logam } \\
\hline 7.1 & Timbal (Pb) & $\mathrm{mg} / \mathrm{kg}$ & \multicolumn{3}{|c|}{ maks. 0,3 } & \multicolumn{3}{|c|}{ maks. 0,3 } \\
\hline 7.2 & Tembaga (Cu) & $\mathrm{mg} / \mathrm{kg}$ & \multicolumn{3}{|c|}{ maks. 20,0} & \multicolumn{3}{|c|}{ maks. 20,0} \\
\hline 7.3 & Timah (Sn) & $\mathrm{mg} / \mathrm{kg}$ & \multicolumn{3}{|c|}{ maks. 40,0} & \multicolumn{3}{|c|}{ maks. 40,0} \\
\hline 7.4 & Raksa (Hg) & $\mathrm{mg} / \mathrm{kg}$ & \multicolumn{3}{|c|}{ maks. 0,03 } & \multicolumn{3}{|c|}{ maks. 0,03 } \\
\hline 8 & Arsen & $\mathrm{mg} / \mathrm{kg}$ & \multicolumn{3}{|c|}{ maks. 0,1} & \multicolumn{3}{|c|}{ maks. 0,1 } \\
\hline 9 & \multicolumn{8}{|l|}{ Cemaran Mikroba } \\
\hline 9.1 & Bakteri Coliform & $\begin{array}{l}\text { APM/g } \\
\text { atau } \\
\text { koloni/g }\end{array}$ & \multicolumn{3}{|c|}{ maks. 10} & \multicolumn{3}{|c|}{ maks. 10} \\
\hline 9.2 & Salmonella & - & \multicolumn{3}{|c|}{ Negatif / $25 \mathrm{~g}$} & \multicolumn{3}{|c|}{ Negatif / $25 \mathrm{~g}$} \\
\hline 9.3 & $\begin{array}{l}\text { Listeria } \\
\text { monocytogenes }\end{array}$ & - & \multicolumn{3}{|c|}{ Negatif / 25 g } & \multicolumn{3}{|c|}{ Negatif / 25 g } \\
\hline 10 & $\begin{array}{l}\text { Jumlah bakteri } \\
\text { starter }\end{array}$ & koloni/g & \multicolumn{3}{|c|}{$\min .10^{7}$} & & - & \\
\hline
\end{tabular}

\section{Bahan baku dan komposisi yoghurt}

Secara umum bahan baku utama pembuatan yoghurt adalah susu. Susu sebagai bahan baku produk yoghurt memiliki banyak macam dan juga standar mutu yang sudah diatur oleh BSN melalui SNI. Adapun salah satu jenis susu yang standar mutunya sudah ditetapkan oleh SNI yaitu susu UHT (Ultra-High Temperature) yang merupakan susu yang disterilisasi pada suhu $135^{\circ} \mathrm{C}$ selama 2 detik, dengan atau tanpa zat tambahan dan dikemas secara aseptik. Standar mutu mengenai susu UHT disampaikan pada SNI 01-3950-1998 yang ditampilkan pada Tabel 
2. Selain itu BSN juga mengatur standar mutu untuk jenis susu yang lainnya seperti susu cair plain, minuman susu, susu bubuk rasa, susu pasteurisasi, susu bubuk, susu kental manis, susu evaporasi, dan susu segar sapi.

Selain susu, umumnya beberapa merk yang beredar menggunakan gula dan air sebagai bahan baku. Penambahan gula umumnya bertujuan untuk memberikan rasa manis pada yoghurt, karena pada dasarnya yoghurt memiliki rasa masam. Karena bakteri pada yoghurt membutuhkan laktosa sebagai bahan baku yang akan diubah menjadi asam laktat, beberapa merk menambahkan laktosa untuk kemudian diubah menjadi asam laktat [32]. Sebagai produk kemasan yang dipasarkan di minimarket, konsistensi yoghurt haruslah diperhatikan. Meskipun mampu menghasilkan emulsifier alami, yoghurt tanpa lemak cenderung lebih mudah rusak, maka penambahan penstabil menjadi penting untuk produk yoghurt kemasan supaya lebih tahan lama. Kebanyakan merk yoghurt mengkombinasikan penggunaan penstabil nabati dan hewani.

Tabel 2. Syarat mutu yoghurt menurut SNI 01-3950-1998 [28]

\begin{tabular}{|c|c|c|c|c|}
\hline \multirow[b]{2}{*}{ No } & \multirow[b]{2}{*}{ Kriteris Uji } & \multirow[b]{2}{*}{ Satuan } & \multicolumn{2}{|c|}{ Persyaratan } \\
\hline & & & Susu UHT tawar & $\begin{array}{l}\text { Susu UHT } \\
\text { berperisa }\end{array}$ \\
\hline 1 & Keadaan & & & \\
\hline 1.1 & Warna & - & $\begin{array}{c}\text { Khas, normal } \\
\text { sesuai label }\end{array}$ & $\begin{array}{l}\text { Khas, normal } \\
\text { sesuai label }\end{array}$ \\
\hline 1.2 & Bau & - & $\begin{array}{l}\text { Khas, normal } \\
\text { sesuai label }\end{array}$ & $\begin{array}{l}\text { Khas, normal } \\
\text { sesuai label }\end{array}$ \\
\hline 1.3 & Rasa & - & $\begin{array}{l}\text { Khas, normal } \\
\text { sesuai label }\end{array}$ & $\begin{array}{l}\text { Khas, normal } \\
\text { sesuai label }\end{array}$ \\
\hline 2 & Protein $(b / b)$ & $\%$ & $\min .2,7$ & $\min .2,4$ \\
\hline 3 & Lemak (b/b) & $\%$ & $\min .3,0$ & $\min .2,0$ \\
\hline 4 & $\begin{array}{l}\text { Bahan kering tanpa } \\
\text { lemak (b/b) }\end{array}$ & $\%$ & $\min .8,0$ & $\begin{array}{c}\text { Tidak } \\
\text { dipersyaratkan }\end{array}$ \\
\hline 5 & Total padatan & - & $\begin{array}{c}\text { Tidak } \\
\text { dipersyaratkan }\end{array}$ & $\min .12$ \\
\hline 6 & Pewarna tambahan & - & $\begin{array}{c}\text { Tidak } \\
\text { dipersyaratkan }\end{array}$ & sesuai \\
\hline 7 & Cemaran logam & & & \\
\hline 7.1 & Timbal (Pb) & $\mathrm{mg} / \mathrm{kg}$ & maks. 0,30 & maks. 0,30 \\
\hline 7.2 & Tembaga (Cu) & $\mathrm{mg} / \mathrm{kg}$ & maks. 20,0 & maks. 20,0 \\
\hline 7.3 & Seng (Zn) & $\mathrm{mg} / \mathrm{kg}$ & maks. 40,0 & maks. 40,0 \\
\hline 7.4 & Timah (Sn) & $\mathrm{mg} / \mathrm{kg}$ & maks. 40,0 & maks. 40,0 \\
\hline 7.5 & Raksa (Hg) & $\mathrm{mg} / \mathrm{kg}$ & maks. 0,03 & maks. 0,03 \\
\hline 8 & Cemaran Arsen & $\mathrm{mg} / \mathrm{kg}$ & maks. 0,10 & maks. 0,10 \\
\hline 9 & Cemaran mikroba & & & \\
\hline 9.1 & Angka lempeng total & Koloni/g & 0 & 0 \\
\hline
\end{tabular}

Terdapat 10 merk yoghurt yang dilihat komposisi dan sertifikasi halalnya antara lain merk $A$ (Cimory), B (Elle\&Vire), C (Kin), D (Greenfields), E (Biokul), F (Heavenly Blush), G (Yoplait), H 
(Yoforia), I (Emmi), dan J (Yummy). Komposisi beberapa merk yoghurt yang kini beredar di Indonesia ditampilkan pada Tabel 3. Sebagian besar produk yoghurt yang beredar sudah memiliki sertifikasi halal dari MUI, termasuk merk $C$ yang diimpor dari Bulgaria sudah memiliki sertifikat halal MUI. Adapun merk B (Prancis) yang memiliki sertifikat halal dari Halal Quality Control (HQC) dari Prancis, sertifikasinya telah diakui MIU dan layak edar. Produk dengan merk I memiliki logo halal pada produknya, namun belum dapat dipastikan dari mana sertifikasi halalnya didapatkan. Yoghurt dengan merk $G$ tidak memiliki logo halal dalam kemasannya, yang berarti kemungkinan merk tersebut belum memiliki sertifikasi halal.

Kesepuluh merk yoghurt yang ada pada Tabel 3 merupakan merk yang beredar di pasar Indonesia. Merk tersebut dipilih untuk mempermudah pembaca memahami kandungan yang terdapat pada beberapa merk yoghurt yang beredar di pasaran Indonesia. Selain produkproduk lokal yang memiliki sertifikasi halal dari MUI, ada pula merk yoghurt yang belum memiliki sertifikasi halal yang harus diperhatikan oleh konsumen. Selain itu ada pula produk yang memiliki sertifikasi halal yang tidak berasal dari MUI, namun sudah diakui oleh MUI. Karena saat ini proses jual beli menjadi sangat cepat dan tidak terbatas, khususnya jual beli melalui aplikasi digital, memerhatikan status kehalalan suatu produk olahan khususnya yang melibatkan mikroorganisme menjadi sangat penting bagi konsumen.

\section{Titik kritis yoghurt}

Berdasarkan pembahasan mengenai proses produksi yoghurt, dan meninjau komposisi yoghurt, maka terdapat beberapa titik kritis untuk produk olahan yoghurt. Jika ditinjau dari proses produksinya, yoghurt melalui tahapan penting dalam proses pembuatannya yaitu proses fermentasi. Setiap produk olahan fermentasi memiliki titik kritis yaitu pada tahapan penyimpanan, dan penyegaran mikroba. Pada tahapan ini biasanya bakteri hasil isolasi, atau yang dibeli dari bank kultur disimpan dalam media agar miring. Media yang umum digunakan mengandung gliserol yang berasal dari lemak hewan dan laktosa yang merupakan hasil samping pengolahan keju yang melibatkan enzim hewan. Titik kritis tahapan ini terletak pada hewan yang menjadi sumber gliserol dan enzim hewan yang digunakan. Apabila gliserol dan enzim diambil dari hewan yang halal dan disembelih sesuai syariat maka proses ini menjadi halal dan bakteri dapat digunakan untuk proses selanjutnya [11]. Bakteri asam laktat yang digunakan untuk proses fermentasi yoghurt berasal dari perut hewan seperti sapi, kambing, domba, atau unta. Apabila tahapan isolasi dilakukan dengan cara sesuai syariat yaitu menyembelih hewan sesuai dengan syariat terlebih dahulu, maka bakteri dapat digunakan untuk proses selanjutnya dan tidak lagi menjadi titik kritis.

Setelah memastikan bakteri yang akan digunakan sudah memenuhi standar dan boleh digunakan, selanjutnya adalah memastikan bahan baku yang digunakan halal. Bahan baku utama pembuatan yoghurt pada umumnya adalah susu sapi murni yang disterilisasi. Sebagian besar industri yoghurt menggunakan susu sapi murni sebagai bahan baku. Susu murni berada di positive list MUI yang artinya bahan ini tidak memiliki titik kritis [33]. Sebagian proses menggunakan air dan diketahui bahwa air memiliki titik kritis apabila melalui proses penyaringan dengan menggunakan karbon aktif. Umumnya karbon aktif digunakan berasal 
Tabel 3. Komposisi yoghurt yang beredar di pasaran

\begin{tabular}{|c|c|c|c|c|c|c|c|c|c|c|}
\hline Merk & A & B & C & D & $E$ & $\mathbf{F}$ & G & $\mathbf{H}$ & I & J \\
\hline Produksi & Bogor & Perancis & Bulgaria & Babadan & Bekasi & Bogor & Turki & Bandung & Swiss & Jakarta \\
\hline \multicolumn{11}{|l|}{ Bahan utama } \\
\hline Susu sapi segar & $\mathrm{v}$ & $\mathrm{v}$ & $\mathrm{v}$ & $\mathrm{v}$ & $\mathrm{v}$ & $\mathrm{v}$ & $\mathrm{v}$ & $\mathrm{v}$ & $\mathrm{v}$ & $\mathrm{v}$ \\
\hline Air & $\mathrm{v}$ & - & $\mathrm{v}$ & $\mathrm{v}$ & $\mathrm{v}$ & $\mathrm{v}$ & $\mathrm{v}$ & $\mathrm{v}$ & - & - \\
\hline Gula & $\mathrm{v}$ & $\mathrm{v}$ & $\mathrm{v}$ & $\mathrm{v}$ & $\mathrm{v}$ & - & $\mathrm{v}$ & $\mathrm{v}$ & - & - \\
\hline Laktosa air & - & $\mathrm{v}$ & - & - & - & - & - & - & - & - \\
\hline Protein susu & - & - & - & - & - & - & - & - & v & \\
\hline \multicolumn{11}{|l|}{ Bahan tambahan } \\
\hline Susu skim bubuk & $\mathrm{v}$ & - & $\mathrm{v}$ & $\mathrm{v}$ & $\mathrm{v}$ & $\mathrm{v}$ & - & $\mathrm{v}$ & - & - \\
\hline Susu skim pasteurisasi & - & - & - & - & - & - & - & - & - & $\mathrm{v}$ \\
\hline Susu bubuk full krim & $\mathrm{v}$ & - & - & - & - & $\mathrm{v}$ & - & - & - & - \\
\hline Krim susu cair & - & - & - & $\mathrm{v}$ & & - & - & - & - & \\
\hline Polidekstrosa & - & - & - & $\mathrm{v}$ & & - & - & - & - & \\
\hline Konsentrat susu & - & - & - & - & $\mathrm{v}$ & - & - & - & - & - \\
\hline Penstabil nabati & $\mathrm{v}$ & $\mathrm{v}$ & $\mathrm{v}$ & $\mathrm{v}$ & $\mathrm{v}$ & $\mathrm{v}$ & $\mathrm{v}$ & $\mathrm{v}$ & - & - \\
\hline Penstabil hewani & v & - & - & $\mathrm{v}$ & $\mathrm{v}$ & $\mathrm{v}$ & - & v & - & - \\
\hline L. bulgaricus & $\mathrm{v}$ & - & $\mathrm{v}$ & $\mathrm{v}$ & $\mathrm{v}$ & $\mathrm{v}$ & - & $\mathrm{v}$ & $\mathrm{v}$ & $\mathrm{v}$ \\
\hline S. thermophilus & $\mathrm{v}$ & - & $\mathrm{v}$ & $\mathrm{v}$ & $\mathrm{v}$ & $\mathrm{v}$ & - & $\mathrm{v}$ & $\mathrm{v}$ & $\mathrm{v}$ \\
\hline L. acidophilus & - & - & - & - & $\mathrm{v}$ & - & - & - & $\mathrm{v}$ & - \\
\hline Bifidobacterium & - & - & - & - & $\mathrm{v}$ & - & - & - & - & $\mathrm{v}$ \\
\hline Perisa & $\mathrm{v}$ & $\mathrm{v}$ & v & $\mathrm{v}$ & - & $\mathrm{v}$ & $\mathrm{v}$ & $\mathrm{v}$ & - & - \\
\hline Pewarna & & & $\mathrm{v}$ & - & & - & $\mathrm{v}$ & $\mathrm{v}$ & - & - \\
\hline Potongan buah & - & $\mathrm{v}$ & - & - & - & $\mathrm{v}$ & - & - & - & - \\
\hline Sari buah & & & $\mathrm{v}$ & - & & $\mathrm{v}$ & - & - & - & - \\
\hline Logo halal & MUI & HQC & MUI & MUI & MUI & MUI & - & MUI & - & MUI \\
\hline
\end{tabular}


dari arang kayu atau tulang. Karbon aktif yang digunakan untuk proses penyaringan ini harus dipastikan sumbernya. Apabila menggunakan karbon aktif yang berasal dari tulang hewan, harus dipastikan bahwa tulang hewan yang digunakan berasal dari hewan halal yang disembelih berdasarkan syariat islam [4]. Pada beberapa yoghurt ada pula yang ditambahkan dengan gula pasir, gula pasir sendiri merupakan positive list sama halnya dengan susu murni [32]. Namun, gula akan menjadi titik kritis apabila yang digunakan adalah gula rafinasi. Gula rafinasi merupakan salah satu jenis gula yang melalui tahap dekolorisasi atau penghilangan warna sehingga memiliki warna yang lebih putih dibandingkan gula kristal. Pada tahap tersebut, gula dimurnikan menggunakan karbon aktif yang dapat berasal dari arang kayu atau tulang. Jika karbon aktif berasal dari hewan, perlu dipastikan kehalalannya. Hewan tersebut berasal dari hewan yang diharamkan atau dihalalkan. Apabila berasal dari hewan halal, ditelusur kembali apakah hewan tersebut disembelih sesuai dengan syariat islam atau tidak [4].

Selain bahan baku utama, beberapa jenis yoghurt mengandung zat aditif berupa penstabil, perisa, dan pewarna. Setiap zat aditif ini memiliki titik kritisnya masing-masing. Penstabil biasanya ditambahkan untuk menjaga konsistensi yoghurt agar tetap stabil. Sebagian produk yang beredar di pasaran menggunakan penstabil nabati dan hewani. Penstabil nabati yang banyak digunakan adalah pektin dan lecithin yang berasal dari minyak nabati. Sedangkan penstabil hewani yang banyak digunakan adalah gelatin. Penstabil ini memiliki titik kritis kehalalan karena apabila menggunakan penstabil hewani yang berasal dari hewan haram atau didapatkan dengan cara yang tidak sesuai syariat, maka akan menjadikan produk akhirnya tidak halal. Penambahan perisa ini umumnya dilakukan untuk menutupi rasa khas asam dari yoghurt, sehingga lebih pas untuk lidah konsumen. Apabila perisa tambahan berasal dari buah buahan alami maka perisa ini tidak memiliki titik kritis. Namun apabila perisa yang digunakan mengandung bahan-bahan yang berbahaya bagi kesehatan, maka penambahan perisa menjadikan produk tidak toyyib (baik) sehingga tidak halal. Hal serupa juga berlaku untuk penambahan pewarna yang biasa dilakukan untuk mempercantik tampilan produk [13],[34], [35].

\section{Kesimpulan}

Berdasarkan pembahasan mengenai sejarah, proses produksi, komposisi dan titik kritis kehalalan yoghurt, dapat disepakati bahwa produk olahan ini memiliki titik kritis yang dapat menyebabkan produk menjadi tidak halal. Terlepas dari banyaknya penelitian yang mengatakan manfaat dan kebaikan yang diberikan yoghurt, konsumen tetap harus berhatihati saat akan membeli dan mengkonsumsi yoghurt. Konsumsi yoghurt secukupnya secara teratur baik untuk kesehatan, karena mampu menjaga jumlah bakteri dalam usus dan membantu memaksimalkan penyerapan nutrisi. Namun akan lebih baik apabila mengkonsumsi yoghurt yang sudah memiliki sertifikasi halal dan sesuai dengan SNI. Yoghurt termasuk dalam produk yang dihasilkan dengan adanya penambahan starter mikroba maka metode sertifikasi yang menganut prinsip telusur merupakan metode yang tepat dalam memberikan jaminan halal terhadap produk ini karena jaminan halal didapatkan dari hulu hingga ke hilir. Hendaknya setiap manusia memperhatikan makanan yang masuk terutama makanan halal yang sudah pasti baik, akan membantu menjaga tubuh kita agar tetap sehat. 
Islam mengajarkan bahwa segala sesuatu yang berlebihan itu tidak baik. Hal tersebut juga berlaku dengan yoghurt. Apabila dikonsumsi secara berlebihan, jumlah bakteri asam laktat pada yoghurt akan menghambat pertumbuhan bakteri pembusukan dalam usus, sehingga akan menghambat proses pembusukan dalam usus. Jadilah konsumen yang bijak dalam memilih apa yang akan dikonsumsi.

\section{Referensi}

[1] Dukcapil, "Distribusi Penduduk Indonesia Per Juni 2021: Jabar Terbanyak, Kaltara Paling Sedikit," 2021. https://dukcapil.kemendagri.go.id/berita/baca/809/distribusipenduduk-indonesia-per-juni-2021-jabar-terbanyak-kaltara-paling-sedikit (accessed Nov. 12, 2021).

[2] V.B. Kusnandar, "Sebanyak 86,88\% Penduduk Indonesia Beragama Islam," 2021. https://databoks.katadata.co.id/datapublish/2021/09/30/sebanyak-8688-pendudukindonesia-beragama-islam (accessed Nov. 12, 2021).

[3] World Population Review, "Muslim Population By Country 2021," 2021. https://worldpopulationreview.com/country-rankings/muslim-population-by-country (accessed Nov. 13, 2021).

[4] Y.R. Al-Teinaz, "What is Halal Food?," in The Halal Food Handbook, London: WileyBlackwell, 2020, pp. 9-26.

[5] A. Ginantaka dan E.R. Zain, "Perancangan sistem informasi traceability produk pangan halal ukm unggulan berbasis digital business ecosystem," J. Agroindustri Halal ISSN 2442-3548, vol. 3, no. 2, pp. 170-182, 2017.

[6] M.E.S. Mirghani, N. Ramli, H.M. Salleh, dan F. Octavianti, "An overview of the current analytical methods for halal testing," Contemp. Issues Dev. Glob. Halal Ind., no. November 2019, 2019, doi: 10.1007/978-981-10-1452-9.

[7] R.C. Chandan, A. Gandhi, dan N.P. Shah, "Yoghurt: Historical background, health benefits, and global trade," in Yoghurt in Health and Disease Prevention, N. P. Shah, Ed. Kidlington: Academic Press, 2017, pp. 3-29.

[8] R.C. Chandan, "An overview of yoghurt production and composition," in Yoghurt in Health and Disease Prevention, N. P. Shah, Ed. Kidlington: Academic Press, 2017, pp. 31-47.

[9] K.M. Gawai, S.P. Mudgal, dan J.B. Prajapati, "Stabilizers, colorants, and exopolysaccharides in yoghurt," in Yoghurt in Health and Disease Prevention, N. P. Shah, Ed. Kidlington: Academic Press, 2017, pp. 49-68.

[10] P.K. Singh dan N.P. Shah, "Other fermented dairy products: Kefir and koumiss," in Yoghurt in Health and Disease Prevention, N. P. Shah, Ed. Kidlington: Academic Press, 2017, pp. 87-106.

[11] B. Satiawihardja, S. Mulijani, H. Nuraini, dan K. Syamsu, "Titik Kritis pada Setiap Tahap Proses Fermentasi," 2018. https://www.halalmui.org/mui14/main/detail/titik-kritispada-setiap-tahap-proses-fermentasi (accessed Nov. 12, 2021).

[12] BSN, Petunjuk Teknis Skema Sertifikasi Produk Yoghurt. Republik Indonesia: Lampiran LXXIX Peraturan Badan Standarisasi Nasional, 2019.

[13] Y. Atma, M. Taufik, dan H. Seftiono, "Identifikasi Resiko Titik Kritis Kehalalan Produk Pangan: Studi Produk Bioteknologi," J. Teknologi, vol. 10, no. 1, pp. 59-66, 2018.

[14] S. Pamuji, "Ini Dua Skema Kemenag Fasilitasi Sertifikasi Halal Produk UMK," 2021. https://kemenag.go.id/read/ini-dua-skema-kemenag-fasilitasi-sertifikasi-halal-produkumk-kdeko (accessed Nov. 17, 2021). 
[15] R.C. Chandan, "History and consumption trends," in Manufacturing Yoghurt and Fermented Milk, Chechester: Wiley-Blackwell, 2013, pp. 3-20.

[16] H. Hawksey, Five Nutritious Health Foods, Northants: Science of Life Book, 1971.

[17] M. Bai dkk., "Probiotic Lactobacillus casei Zhang improved the properties of stirred yoghurt," Food Biosci., vol. 37, no. July, p. 100718, 2020, doi: 10.1016/j.fbio.2020.100718.

[18] F. Rul, Yoghurt: Microbiology, organoleptic properties and probiotic potential. 2017.

[19] R.W. Hutkins dan H.A. Morris, "Carbohydrate metabolism by Streptococcus thermophilus: A Review," J. Food Prot., vol. 50, no. 10, pp. 876-884, 1987, doi: 10.4315/0362-028x-50.10.876.

[20] R.C. Chandan dan A. Kilara, Manufacturing Yoghurt and Fermented Milks. Chechester: Wiley-Blackwell, 2013.

[21] P. Hao dkk., "Complete sequencing and pan-genomic analysis of Lactobacillus delbrueckii subsp. bulgaricus reveal its genetic basis for industrial yoghurt production," PLoS One, vol. 6, no. 1, 2011, doi: 10.1371/journal.pone.0015964.

[22] M. Aghababaie, M. Khanahmadi, dan M. Beheshti, "Developing a kinetic model for coculture of yoghurt starter bacteria growth in $\mathrm{pH}$ controlled batch fermentation," J. Food Eng., vol. 166, pp. 72-79, 2015, doi: 10.1016/j.jfoodeng.2015.05.013.

[23] I. Vasilean, R. Segal, dan A. Vasile, "Obtaining fermented dairy products with the yoghurt culture YF-L 812.," Ann. Univ. "Dunarea Jos" Galati - Fascicle VI Food Technol., vol. 35, no. 1, pp. 92-99, 2011.

[24] G.R. Chasoy, I. Chairez, dan E. Durán-Páramo, "Carbon/nitrogen ratio and initial pH effects on the optimization of lactic acid production by Lactobacillus casei subsp casei NRRL-441," Wulfenia, vol. 27, no. 10, pp. 37-59, 2020.

[25] USDA, "Carbon to Nitrogen Ratios in Cropping Systems," USDA Nat. Resour. Conserv. Serv., p. 2, 2011, [Online]. Available: http://www.nrcs.usda.gov.

[26] SNI, “SNI 2981:2009," 2009.

[27] F. Fadlina, M. Nasir, dan Zulfadli, "Analisis Cemaran Logam Berat Timbal dan Arsen pada Susu Kambing Segar dengan Metode Spektrometri Serapan Atom (Studi Kasus di Peternakan Kambing Limpok Darussalam)," 2018.

[28] SNI, "Susu UHT (Ultra High Temperature) SNI 01-3950-1998," Standar Nas. Indones., pp. 1-23, 1998.

[29] R.A. Nasution, "Analisis logam berat timah dan tembaga dalam susu pasteurisasi menggunakan spektrofotometer serapan atom tungku grafit," 2020.

[30] E.M. Silalahi dan E. Purwanti, "Analisis kandungan logam berat timbal ( $\mathrm{Pb}$ ) pada produk olahan susu," J. Food Sci. Technol., vol. 1, no. 1, pp. 1-10, 2021, doi: 10.33830/fsj.v1i1.1455.2021.

[31] Y. H. Diza, T. Wahyuningsih, dan W. Hermianti, "Penentuan jumlah bakteri asam laktat (bal) dan cemaran mikroba patogen pada yoghurt bengkuang selama penyimpanan," $J$. Litbang Ind., vol. 6, no. 1, p. 1, 2016, doi: 10.24960/jli.v6i1.891.1-11.

[32] P. Leong-Morgenthaler, M.C. Zwahlen, dan H. Hottinger, "Lactose metabolism in Lactobacillus bulgaricus: Analysis of the primary structure and expression of the genes involved," J. Bacteriol., vol. 173, no. 6, pp. 1951-1957, 1991, doi: 10.1128/jb.173.6.1951-1957.1991.

[33] MUI, "Daftar Bahan Tidak Kritis (Halal Positive List of Materials) LPPOM MUI," vol. 8358748, no. 51, pp. 4-7, 2013. 
[34] I. Jaswir, E.A. Rahayu, N.D. Yuliana, dan A.P. Roswiem, Daftar Referensi Bahan-bahan yang Memiliki Titik Kritis Halal dan Substitusi Bahan non-Halal. Jakarta: Komite Nasional Ekonomi dan Keuangan Syariah, 2020.

[35] M.M.Z. Butt, "Halal and Shariah Law," in The Halal Food Handbook, Y.R. Al-Teinaz, Ed. London: Wiley-Blackwell, 2020, pp. 27-38. 